\title{
Social Origins of Developmental Risk for Mental and Physical Illness
}

\author{
어 Judy L. Cameron, ${ }^{1}$ Kathie L. Eagleson, ${ }^{2}$ Nathan A. Fox, ${ }^{3}$ Takao K. Hensch, ${ }^{4,5}$ and $\odot$ Pat Levitt ${ }^{2}$ \\ ${ }^{1}$ Department of Psychiatry, University of Pittsburgh, Pittsburgh, Pennsylvania 15213, ${ }^{2}$ Department of Pediatrics, Keck School of Medicine, University of \\ Southern California, Children's Hospital Los Angeles, Los Angeles, California 90027, 32Department of Human Development and Quantitative Methodology, \\ University of Maryland, College Park, Maryland 20742, ${ }^{4}$ Center for Brain Science, Department of Molecular Cellular Biology, Harvard University, \\ Cambridge, Massachusetts 02138, and ${ }^{5}$ F. M. Kirby Neurobiology Center, Department of Neurology, Boston Children's Hospital, Harvard Medical School, \\ Boston, Massachusetts 02115
}

Adversity in early childhood exerts an enduring impact on mental and physical health, academic achievement, lifetime productivity, and the probability of interfacing with the criminal justice system. More science is needed to understand how the brain is affected by early life stress (ELS), which produces excessive activation of stress response systems broadly throughout the child's body (toxic stress). Our research examines the importance of sex, timing and type of stress exposure, and critical periods for intervention in various brain systems across species. Neglect (the absence of sensitive and responsive caregiving) or disrupted interaction with offspring induces robust, lasting consequences in mice, monkeys, and humans. Complementary assessment of internalizing disorders and brain imaging in children suggests that early adversity can interfere with white matter development in key brain regions, which may increase risk for emotional difficulties in the long term. Neural circuits that are most plastic during ELS exposure in monkeys sustain the greatest change in gene expression, offering a mechanism whereby stress timing might lead to markedly different long-term behaviors. Rodent models reveal that disrupted maternal-infant interactions yield metabolic and behavioral outcomes often differing by sex. Moreover, ELS may further accelerate or delay critical periods of development, which reflect GABA circuit maturation, BDNF, and circadian Clock genes. Such factors are associated with several mental disorders and may contribute to a premature closure of plastic windows for intervention following ELS. Together, complementary cross-species studies are elucidating principles of adaptation to adversity in early childhood with molecular, cellular, and whole organism resolution.

Key words: EEG; foster care; limbic; neglect; parvalbumin; sex-dependent

\section{Introduction}

Decades of basic, developmental, clinical, and epidemiological research demonstrate that adverse childhood experiences contribute to increased risk of poor outcomes in cognitive, social, and emotional functioning, as well as poor physical health in childhood, adolescence, and adulthood (Felitti et al., 1998; Edwards et al., 2003; Anda et al., 2006; Nelson et al., 2014). Yet, data from both cross-sectional and longitudinal studies of human participants are for the most part descriptive and correlational, often including retrospective reporting of adverse life events (Nelson et al., 2016; McEwen and McEwen, 2017).

Evidence from studies of human children now suggests that different types of adversity may have different effects on brain

Received Aug. 27, 2017; revised 0ct. 3, 2017; accepted 0ct. 10, 2017.

This work was supported by the John D. and Catherine T. MacArthur Foundation Network on Early Experience and Brain Development to J.L.C., P.L., and N.A.F., Binder Family Foundation to N.A.F., Simms/Mann Institute and Simms/ Mann Chair in Developmental Neurogenetics to P.L., JPB Research Network on Toxic Stress: A Project of the Center on the Developing Child at Harvard University to P.L. and T.K.H., and National Institutes of Health Grants MH41712, MH62931, MH091363, MH067842, UL1 TR001102, P50MH094271, and F31MH100779.

J.L.C. is CEO of Working For Kids: Building Skills. The remaining authors declare no competing financial interests.

Correspondence should be addressed to Dr. Judy L. Cameron, Department of Psychiatry, University of Pittsburgh,

121 Meyran Avenue, Room 321, Pittsburgh, PA 15213. E-mail: jcameron@pitt.edu.

DOI:10.1523/JNEUROSCI.1822-17.2017

Copyright $\odot 2017$ the authors $\quad 0270-6474 / 17 / 3710783-09 \$ 15.00 / 0$ and behavior (Sheridan and McLaughlin, 2014). For example, those exposed to violence or harsh punishment show distinct changes in brain development and stress reactivity compared with those exposed to neglect (Hart and Rubia, 2012). It appears that neglect or deprivation is associated with reductions in cortical thickness, particularly in prefrontal areas involved in complex problem solving, whereas exposure to threat and violence is associated with perturbations in hippocampus and circuits (amygdalaPFC) involved in fear learning. Specific timing of adverse events further impacts the nature of brain development and behavior.

The Bucharest Early Intervention Project represents the first and only randomized controlled trial of a foster care intervention for infants and young children who were exposed to early psychosocial adversity (Zeanah et al., 2003). The study began with an assessment of a large group of young children living in institutions across Bucharest Romania under conditions of neglect. Half of these children were randomized to placement in families living in Bucharest (the Foster Care Group; Smyke et al., 2009); the other half remained in the institutions in which they were living (Care as Usual). Both groups were followed prospectively across childhood and adolescence. The intervention, which included both psychological and material support to the foster families, began at randomization (mean age 22 months) and ended when 

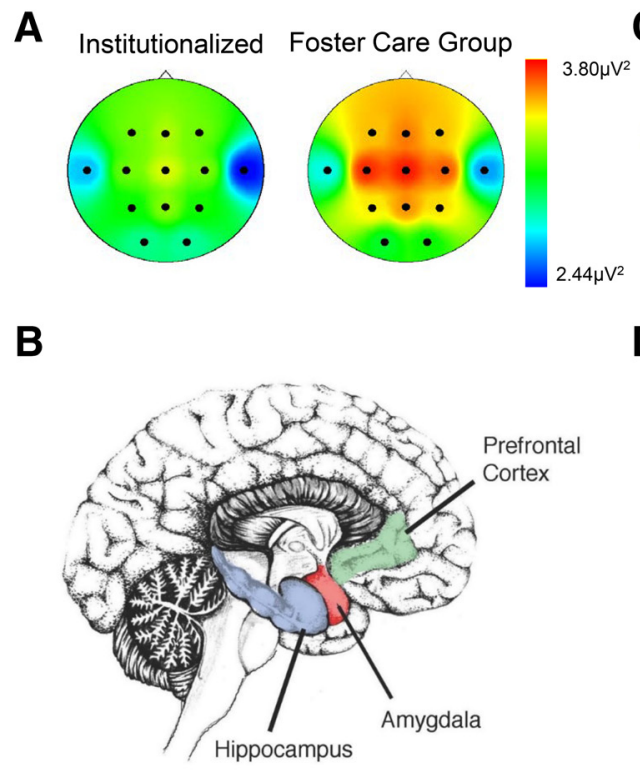
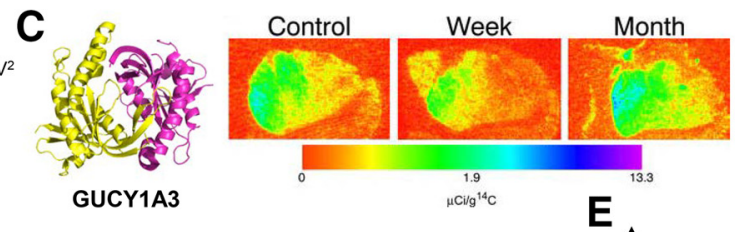

D

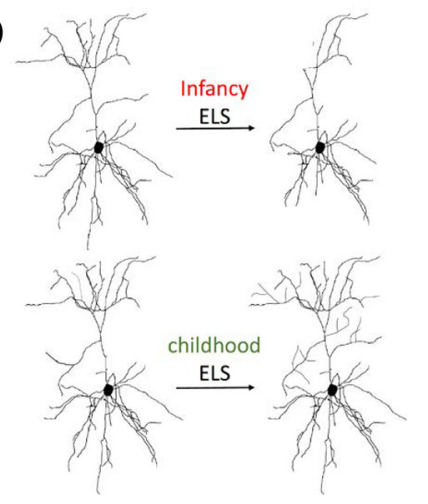

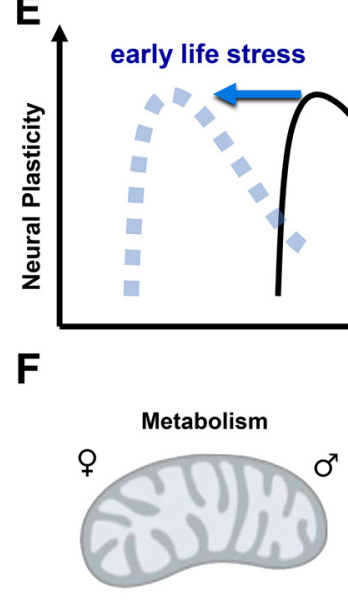

Figure 1. Impact of early life stress across species. $\boldsymbol{A}$, Analysis of EEG in children randomized for Foster Care, or Care as Usual in the Bucharest Early Intervention Study. There is significant reduction in alpha power in children randomized to Care as Usual in the institution, which reflects a disruption of normal developmental increases in information processing in frontal and central cortical regions (Marshall et al., 2004; Vanderwert et al., 2010). These effects are largely corrected only if foster care begins younger than 24 months of age. $\boldsymbol{B}$, Limbic structures, which are particularly sensitive to ELS. C, 3D structure of GUCY1A3, and representative pseudocolored images depicting regional amygdala expression of GUCY1A3 mRNA in 3 animals: a control, maternally raised monkey, a week, 1 week separated monkey, and a month, 1 month separated monkey (Sabatini et al., 2007). D, Stress experienced at different developmental stages results in distinct changes in neuronal morphology. Depicted are dendritic arbors of neurons in prefrontal cortex. Early adversity in the form of disrupting infant-maternal interactions results in reduced arbors, whereas disruption later in development generates a paradoxical increase in dendritic growth (Bock et al., 2005; Xie et al., 2013). $\boldsymbol{E}$, ELS in the first postnatal week results in an accelerated timing of a critical period for limbic circuit plasticity (Callaghan and Richardson, 2011; Bath et al., 2016). $\boldsymbol{F}$, ELS in the first postnatal week in mice, followed by discovery-based comparative proteomics, yields both increased and decreased expression of specific mitochondrial proteins that are involved in respiration and cellular metabolism. These changes in the hippocampus differ by sex.

a child reached 54 months. At multiple time points, children were assessed across a number of different domains, including cognitive functioning, socio-emotional responses, brain activity (measured with EEG), brain structure and connectivity (measured with MRI), and psychiatric status.

Initial results revealed significant impacts on all domains of functioning in young children who were living in Bucharest institutions. They were significantly delayed in intellect (IQ) (Smyke et al., 2007), had abnormal attachment-like behaviors toward caregivers (Zeanah et al., 2005), displayed significantly reduced EEG alpha power (Marshall et al., 2004) (Fig. 1A), and had multiple abnormal psychological behaviors, including stereotypies and aggressive behaviors (Zeanah et al., 2009). EEG alpha power reflects synchronous neural activity that is associated with visual attention and alertness. Low EEG power is consistent with dampened brain metabolism (Buzsaki et al., 2007). This pattern of findings is consonant with a long history of reports regarding effects of institutionalization on infant brain and behavioral development (Nelson et al., 2016).

Postrandomization, children were followed up at 30,42 and 54 months, as well as at 8 and 12 years of age. Regarding cognitive functioning, children randomized to Foster Care displayed higher IQ scores compared with those remaining in Care as Usual at each of the assessment points. Interestingly, at the early assessments (30, 42, and 54 months), there appeared to be a critical period for the impact of the intervention. Those children placed before 24 months were more likely to have higher scores compared with those randomized thereafter (Nelson et al., 2007). This pattern of intervention and timing effects held true not only for IQ but also for attachment behavior (Smyke et al., 2010) and EEG alpha activity (Fig. 1A) (Vanderwert et al., 2010).
At age 12, intervention effects for IQ and EEG alpha activity persisted, but the timing effects were lost (Almas et al., 2016; Vanderwert et al., 2016). Some domains, such as white matter development, psychiatric status, and socio-emotional responding, exhibited intervention effects across assessment points without evidence of timing effects (Humphreys et al., 2015; Bick et al., 2015). Other domains, such as measures of gray matter volume (Sheridan et al., 2012), executive function (Bos et al., 2009), or attention deficit hyperactivity disorder symptoms (Humphreys et al., 2015), showed no signs of an intervention effect. In these latter domains, all children with a history of institutionalization had less gray matter volume, poor executive skills, and heightened symptoms of attention deficit hyperactivity disorder.

Attachment held particular importance for understanding psychiatric outcomes. Children placed into foster homes who established secure attachments with their foster caregivers were less likely to develop such symptoms compared with those who did not. In girls with a history of neglect and internalizing disorders, the development of secure attachments at 42 months fully mediated the effects of intervention (McLaughlin et al., 2012). Subsequently, we determined that caregiving quality (the degree of sensitivity and responsiveness of the caregiver to the child) predicted psychiatric symptoms and degree of psychiatric impairment at 54 months of age. Security of attachment at 42 months was a mediator of this association with a path through secure attachment to reductions in psychopathology at 54 months of age (McGoron et al., 2012).

One overarching mechanism by which early adversity might affect brain and behavior is through the stress response system, influencing at least some aspects of human development. Extensive evidence suggests that caregivers play a critical role in regu- 
lating responses to stress in young children. Early regulation, or lack thereof, may have a lasting effect upon stress response system development. To examine this possibility, the stress systems of children in the Bucharest Early Intervention Project were challenged (at age 12) with the Trier Social Stress Test. Those who were randomized to Care as Usual displayed a blunted stress response as measured both by autonomic and hypothalamicpituitary-adrenal axis reactivity. A blunted stress response is also observed in postinstitutionalized children adopted into United States homes (Gunnar et al., 2009). Instead, children randomized to the Foster Care intervention had more normative responses, and those randomized before 24 months of age were no different from typical community controls of that age (McLaughlin et al., 2015).

This work illustrates the need to understand the effects of early adversity on developmental outcomes, the importance of intervention early in life, and the long-term perturbations by adversity on brain and behavioral development.

\section{Biological impact dependent upon stress timing, neural development state, and poststress parental interaction}

Nonhuman primate models have long been used to undertake mechanistic studies of how early life stress (ELS) impacts behavior and brain development, in part because they exhibit many behavioral and physiological characteristics comparable with those of children experiencing ELS. These include increased anxious behaviors, aberrant attachment patterns, and changes in central neurotransmitter levels, including serotonin, norepinephrine, and dopamine, adrenal axis regulation, and social behavior and brain structure in the long term (Harlow and Zimmerman, 1959; Harlow and Suomi, 1974; Suomi et al., 1975; Coplan et al., 1998; Sánchez et al., 2001; Winslow, 2005; Knudsen et al., 2006; O'Connor and Cameron, 2006; Sabatini et al., 2007; Spinelli et al., 2009, 2010; de Campo et al., 2017). We focus here on limbic circuitry (Fig. 1B), which is particularly sensitive to ELS.

Impact of the timing of exposure on brain and behavioral responses to stress was explored in a series of studies with monkeys (Knudsen et al., 2006; O'Connor and Cameron, 2006; Sabatini et al., 2007; de Campo et al., 2017). Rhesus macaques were reared from 1 week of age with their mothers in social housing with penmates of various ages and both sexes. The social stress was removal of their mother from the pen environment at either 1 week, 1 month, 3 months, or 6 months of age. Monkeys whose mothers were removed from the social group at 1 week of age initially showed self-comforting behaviors, such as rocking and thumb-sucking, and decreases in social interaction with other monkeys. They later continued to have low levels of social contact and displayed increases in anxious behavior.

In contrast, monkeys whose mothers were removed from the social group at 1 month of age initially showed social withdrawal but soon thereafter exhibited a large increase in seeking social interaction which remained apparent throughout development into adulthood. They showed increased levels of vigilance in response to social cues. Monkeys whose mothers were removed from the social group at 3 months of age showed no significant differences in social behavior from the control group, whose mothers were removed at 6 months of age, an age when female monkeys typically leave their offspring to form consortships with males in the next breeding season. For 1 week and 1 month separated monkeys, behavioral differences persisted stably into adulthood (Knudsen et al., 2006; O'Connor and Cameron, 2006).

We further examined the brains of a second group of monkeys at 3 months of age after separation at 1 week or 1 month of age as described above. Gene microarrays were used to look for differences in transcript expression in the amygdala (Sabatini et al., 2007). This structure is established as having a clear role in social, anxious, and depressive behaviors in the nonhuman primate (Baron-Cohen et al., 2000; Emery et al., 2001; Drevets et al., 2002; Amaral, 2003; Bauman et al., 2004; Etkin et al., 2004; Lorberbaum et al., 2004). Comparing gene expression in the same monkeys in which behavior was carefully characterized throughout development enables a genes-to-behavior approach to directly examine linkages (Nelson et al., 2002).

Guanylate cyclase $1 \alpha 3$ (GUCY1A3), the gene that was most differentially expressed between 1 week and 1 or 6 month separated monkeys (Sabatini et al., 2007), showed a strong positive correlation to normal social behaviors, along with a negative correlation to self-comforting behaviors (Fig. $1 C$ ). Notably in the mouse, knockdown of GUCY1A3 in the amygdala is associated with increased anxiety (Werner et al., 2004) and also disrupts migration and neurite outgrowth of developing inhibitory neurons (Mandal et al., 2013), key determinants of critical periods of brain plasticity (see below).

Follow-up studies were performed in the para-laminar nucleus of the amygdala, which develops later and would therefore be likely to show altered neuronal maturation genes in response to stress. Indeed, selective downregulation was found there for tbr1 (de Campo et al., 2017), a transcription factor directing neuroblasts to differentiate into glutamatergic neurons (Hodge et al., 2012). Thus, maternal separation has differential effects on amygdala gene expression reflecting specific trajectories of brain maturation, reinforcing the concept that a circuit's developmental stage contributes essentially to its response to ELS.

Likewise, the ability of an intervention (adoption by an attentive mother) to remediate aberrant behaviors resulting from ELS is also dependent upon the timing of the intervention (Knudsen et al., 2006; O'Connor and Cameron, 2006). One week separated monkeys paired with an experienced mother at $25 \mathrm{~d}$ of age displayed completely normal social behavior as they grew up, whereas pairing at $35 \mathrm{~d}$ of age only partially restored normal social behavior and those paired at $45 \mathrm{~d}$ showed virtually no restoration of normal social behavior (Knudsen et al., 2006; O'Connor and Cameron, 2006). These studies in the monkey provide clear evidence that the timing of stress exposure, or the interventions to remediate it, is a significant factor in determining the long-term consequences of ELS.

\section{Neurobiological signatures of windows of vulnerability}

Multiple rodent models have addressed short- or long-term behavioral and neuronal structural changes due to ELS (Walker et al., 2017). Most have focused in adults on changes in emotion regulation, cognition, risk for obesity, immune dysregulation, cardiovascular disease, or cancer. Specific cellular and molecular mechanisms through which ELS influences health remain relatively elementary, with the physiological consequences defined as allostatic load (Ellis and Boyce, 2011; Danese and McEwen, 2012; McEwen et al., 2015). In the brain, region-specific "critical periods" in infancy and childhood are developmental windows of opportunity/vulnerability characterized by high rates of synaptogenesis and synaptic plasticity (Hensch, 2004; Marín, 2016). In both human and animal species, such circuit rewiring occurring early in life imposes long-term effects that persist into adulthood. Ultimately, the proper timing and sequence of these critical periods across brain regions orchestrate the emergence of higher cognitive functions, such as language or sensory integration.

Synaptic pruning is a hallmark of critical period plasticity. This can be quantified physiologically, and anatomically at the 
ultrastructural level or by counting dendritic spines on excitatory pyramidal cells of the cerebral cortex. Importantly, the extent and direction of experience-induced synaptic changes in cortical areas correlate with time windows of neuronal as well as endocrine development (Mataga et al., 2004; Elston et al., 2009). Repeated brief maternal separation in newborn rats before a stress hyporesponsive period of the hypothalamic-pituitary-adrenal axis significantly reduces dendritic spine density in layer II/III pyramidal neurons of the prefrontal cortex (Fig. 1D). Instead, separation during this hyporesponsive period has no effect and, after this period in young rats, results in spine increase (Fig. 1D). In contrast, spine densities in adolescent somatosensory cortex are enhanced independent of the time of separation (Bock et al., 2005), then become persistently unstable due to potentially increased microglial motility (Takatsuru et al., 2009, 2015). Thus, ELS alters the synaptic balance in limbic and sensory cortices in a regionspecific manner reflecting maturational stage of endocrine and neuronal systems.

Maternal separation in rodents, however, yields inconsistent results on behavior, which may reflect differences in strain, sex, or reunion response (Moore and Morelli, 1979; Millstein and Holmes, 2007; Mehta and Schmauss, 2011; Savignac et al., 2011). To address this, an alternative limited-bedding paradigm was initially developed in rats (Gilles et al., 1996), obviating the requirement for overt separation of pups and dams typically used in rodent ELS models (Rice et al., 2008; Walker et al., 2017). This paradigm induces inconsistent and fragmented maternal care (Heun-Johnson and Levitt, 2016), which has since been validated and adopted for use with mice by multiple laboratories (Rice et al., 2008; Wang et al., 2011, 2012, 2013; Gunn et al., 2013; Malter Cohen et al., 2013; Liao et al., 2014; Kohl et al., 2015; Naninck et al., 2015; Yang et al., 2015; Arp et al., 2016; Bath et al., 2016, 2017; Liu et al., 2016; McIlwrick et al., 2016, 2017; Yam et al., 2017). The paradigm provides an ethologically relevant framework for addressing heritability of risk-, sex-, and developmentally dependent influences that determine outcomes following ELS. As we detailed by video analyses, changes in both maternal care and pup responses to this environment are complex, with both likely contributing to enduring alterations in brain function (HeunJohnson and Levitt, 2016).

Cellular analyses in the limited-bedding model to date have focused primarily on neuronal architecture and function. Except for two studies, which report altered astrocyte glutamate transporter function in the hypothalamus (Gunn et al., 2013) and a premature increase in myelin basic protein in the hippocampus (Bath et al., 2016), the involvement of non-neuronal cells has not been studied. Based on their central roles in regulating neuronal development and function, including synaptogenesis (Hong and Stevens, 2016), disruption of non-neuronal cells likely contributes to the long-term effects of ELS on neuronal function and behavioral outcomes. Moreover, recent studies reinforce the concept that the maturational state of neural circuits during development is likely to determine ELS responses.

For example, reduced expression of the Met receptor tyrosine kinase, which results in advanced maturation of hippocampal circuits (Qiu et al., 2014; Peng et al., 2016), when combined with ELS, results in hippocampal structural changes that parallel those observed when ELS is administered later in development $(\mathrm{H}$. Heun-Johnson and P.L., unpublished observations). These and other data place an emphasis on measurements that include assessment of developmental trajectories of specific phenotypes after ELS, not simply "end state" outcomes. This experimental approach is valid for brain, behavior, and peripheral organ functions that reflect states of health.

\section{Inhibitory circuit impact and reversibility of early life adversity}

Pioneering work in sensory systems has revealed inhibitory interneuron function to be essential for normal critical period timing (Hensch, 2005). When glutamic acid decarboxylase (GAD65), which is responsible for GABA synthesis at axon terminals, is deleted from mice, critical period plasticity for vision (ocular dominance) (Hensch et al., 1998), hearing (tonotopy) (Barkat et al., 2011), or multisensory integration (insula) (Gogolla et al., 2014) is prevented until inhibition is restored, such as by the benzodiazepine agonist, diazepam. Maturation of a specific, local inhibitory network composed of parvalbumin-positive $\left(\mathrm{PV}^{+}\right)$ large basket cells derived from the medial ganglionic eminence drives critical period onset (Takesian and Hensch, 2013). Indeed, manipulations of excitatory/inhibitory balance are so powerful that a brain region may be before, during, or past its critical period regardless of chronological age. This finely tuned excitatory/inhibitory balance is highly susceptible to alteration and pathology in cognitive disorders, such as autism and schizophrenia, leading to subsequent mistiming of plastic windows that derail development (Leblanc and Fagiolini, 2011; Do et al., 2015; Marín, 2012).

Fast-spiking $\mathrm{PV}^{+}$large basket cells mature at different rates in different brain regions (del Rio et al., 1994; Conde et al., 1996), thereby playing a central role in the proper sequential timing of critical periods (Hensch, 2005). These cells exert temporal control over the information flow to the pyramidal neurons and are gradually surrounded by perineuronal nets (PNNs), which encapsulate the maturing PV-cell body and its proximal neurites. Chondroitin sulfate proteoglycans in the PNN and myelin factors, produced by oligodendrocytes, bind to the Nogo receptor (Dickendesher et al., 2012), which acts in a complex with immune genes to restrict plasticity beyond a critical period (Atwal et al., 2008; Bochner et al., 2014). The best evidence that disruption of the development of $\mathrm{PV}^{+}$interneurons and maintenance of their PNNs are pathophysiological targets comes from studies of schizophrenia (Lewis et al., 2012; Do et al., 2015; Marín, 2016).

A key feature of fast-spiking $\mathrm{PV}^{+}$cells is their high metabolic demand (Buzsaki et al., 2007), which generates abundant reactive oxygen species. The PNNs serve to protect $\mathrm{PV}^{+}$cells from this oxidative stress (Cabungcal et al., 2013). But they can eventually succumb to the damage themselves, resulting in PNN loss and transiently prolonged critical period plasticity (Morishita et al., 2015) that may contribute to circuit instability in the etiology of mental illness (Do et al., 2015). Maternal and perinatal immune challenge (Meyer et al., 2008; Jenkins et al., 2009), parental separation (Brenhouse and Andersen, 2011), and social isolation (Harte et al., 2007; Schiavone et al., 2009) have all been shown to lead to anomalies in hippocampal and/or prefrontal $\mathrm{PV}^{+}$ circuits.

The impact of ELS on these critical period "triggers" and "brakes" is then of great interest. Factors that may accelerate or delay GABA circuit maturation, such as BDNF (Huang et al., 1999; Bath et al., 2013), Clock gene expression (Kobayashi et al., 2015; Marco et al., 2016), Otx2 (Sugiyama et al., 2008; Pena et al., 2017), or the GUCY1A3 mentioned above (Sabatini et al., 2007), may be vulnerable to ELS, predicting a shift in developmental timing. Indeed, limbic circuits underlying fear extinction are particularly sensitive to ELS (Fig. 1B). Both rats (Callaghan and Richardson, 2011) and mice (Bath et al., 2016) after ELS show an accelerated 
transition to mature fear memories that are more enduring (Fig. $1 E)$. This transition normally reflects in part the emergence of PNNs in the basolateral amygdala (Gogolla et al., 2009), suggesting that an earlier biochemical maturation of $\mathrm{PV}^{+}$circuits may underlie the effects of ELS. Thus, not only does ELS deprive the pups of vital caregiver interactions early in life, it may also prematurely limit the extent of critical period windows of opportunity to potentially correct their derailed circuitry.

\section{Sex- and timing-based vulnerabilities of the biological impact of ELS}

Emerging evidence points to neurodevelopmental origins of most psychiatric disorders, spanning internalizing and externalizing behaviors (Leonardo and Hen, 2008; Pechtel and Pizzagalli, 2011). Epidemiological data in humans reveal significant differences between females and males in the incidence of psychiatric disorders. In particular, internalizing disorders, such as posttraumatic stress disorder (Kessler et al., 1995), panic disorder, generalized anxiety, and major depressive disorder (Somers et al., 2006; Eaton et al., 2012) are more prevalent in women, whereas men have a higher risk for externalizing disorders, such as attention deficit hyperactivity disorder, substance abuse, autism, and schizophrenia (for review, see Cover et al., 2014). It is likely that ELS will predispose neuronal circuits to internalizing or externalizing disorders in a stress type- and sex-dependent manner (Keyes et al., 2012).

The Virginia twin study of adolescent (age 8 -16 years) behavioral development confirmed that girls are more affected by emotional disorders, and boys more in behavioral disorders (Eaves et al., 1997; Simonoff et al., 1997). This suggests a sex-environment interaction in the development of psychiatric disorders. For example, sex differences in anxiety emerge from adolescence, with females more susceptible especially if they have experienced ELS (for review, see Bale and Epperson, 2015). Likewise, we found that ELS in mice predisposes to internalizing or externalizing behaviors in a sex-dependent manner, which may reflect differentially wired inhibitory circuitry in their prefrontal cortex (Z.Y., H.S.K., C.J., and T.K.H., unpublished observations; Holland et al., 2014).

There is considerable evidence that many sex-dependent outcomes to prenatal stressors are mediated by sex-dependent effects on the placenta (Mueller and Bale, 2007, 2008; Goel and Bale, 2009; Bale, 2011; Bronson and Bale, 2014; Howerton and Bale, 2014; Bronson et al., 2017). Recent studies indicate that, even in the absence of placental effects, the early postnatal period represents a distinct developmental window for sex-dependent responses to early life stressors (Kawakami et al., 2007; Coutellier and Würbel, 2009; Kikusui and Mori, 2009; Gross et al., 2012; Kawakami et al., 2013; Naninck et al., 2015; Arp et al., 2016; Fuentes et al., 2016; Lerch et al., 2016; Bath et al., 2017; de Azeredo et al., 2017; Yam et al., 2017). For the most part, the mechanisms underlying sex-dependent outcomes in response to exposure to stressors during this later period are poorly understood.

The application of discovery-based strategies, such as comparative genomic and proteomic profiling of vulnerable circuits, also can guide investigations of mechanisms that underlie how ELS disrupts brain and peripheral organ development and function. Recent application of one such method, isobaric tag for relative and absolute quantitation, on brain tissue isolated at various times in development, inclusive of both sexes, revealed that prominent among a disrupted developmental proteome are proteins involved in ATP production and mitochondrial homeostasis. Although requiring further investigation, the mitochondria- associated protein changes are consistent with temporal and sex influences on cellular responses to ELS during development (Fig. $1 E$ ) (K.L.E. and P.L., unpublished observations). The findings are aligned with those described by McEwen and colleagues (Picard and McEwen, 2014; Picard et al., 2014, 2015, 2017) following psychosocial stress. Direct measures of mitochondria-associated phenotypes reveal that ELS using the limited bedding paradigm results in sex-dependent adaptations that likely reflect functional short- and longer-term functional changes (K.L.E. and P.L., unpublished observations).

Mitochondrial dysfunction has been associated with a variety of brain-based and peripheral disorders that display a sex bias, including affective disorders (Chang et al., 2015; Klinedinst and Regenold, 2015; Bansal and Kuhad, 2016), diabetes (Koliaki and Roden, 2016; Wanagat and Hevener, 2016), liver disorders (Pessayre, 2007; Serviddio et al., 2008; Grattagliano et al., 2012), and neurodegenerative disorders (Wallace, 1999). Sex differences in mitochondrial function have been reported and are typically associated with levels of circulating gonadal hormones following puberty (Gaignard et al., 2015) and the decline in estrogen and progesterone following menopause (Irwin et al., 2012; Rettberg et al., 2014; Yin et al., 2015).

These may underlie, at least in part, the increased vulnerability of one sex to certain pathological processes. There remains, however, a limited understanding of the developmental origins of sex-dependent mitochondrial dysfunction, which is particularly relevant in the context of neurodevelopmental disorders that manifest before puberty. This is a rich area of investigation in establishing how early adaptive physiological responses to allostatic load result in maladaptive, long-term functions that can have such profound impacts on physical and mental health.

In conclusion, early studies of the long-term effects of ELS or adversity in early childhood, in both animal and human studies, focused primarily on describing a host of behavioral outcomes that were characterized by poorer ability of an individual to adapt to the ever-changing contexts that characterize life, including perturbed attention skills, aggressive behaviors, difficulty with social relationships (i.e., attachment disorders), and difficulty in interpreting the world around them (i.e., increased display of a myriad of anxious and depressive behaviors). The similarity of the behavioral outcomes led to the general belief that experiencing a variety of early life adversities can set an individual on an alternative developmental trajectory that may differ in severity but was characterized by a rather uniform set of behavioral characteristics. However, as science has delved further into mechanistic studies, the specificity of the impact of early life adversities on brain development is becoming apparent. The nature of the adversity, whether it involves abuse, fear, or neglect, matters, and it is likely that as we understand these phenomena better, we will be able to define specific neural circuits that respond to each type of adversity, and differences in sensitivity to long-term alterations in function. The timing of experiencing adversity matters, as neural circuits that are actively developing at the time the stress is experienced are most likely to be affected by the stress. Factors that alter the developmental state of circuits will influence their response to ELS. Periods when neural circuits are plastic and actively developing represent periods of increased sensitivity to the impact of both stress exposure and remediating interventions. The sex of the individual matters. Early life adversities can have sex-specific effects on developing neural circuits. As neuroscience continues to advance in integrating measures across different levels of resolution, we believe that specific outcomes of exposure to early life adversities will become more predictable. 
This will provide a clearer understanding of how to effectively intervene to facilitate adaptation that redirects an individual onto a trajectory of more normative development.

\section{References}

Almas AN, Degnan KA, Nelson CA, Zeanah CH, Fox NA (2016) IQ at age 12 following a history of institutional care: findings from the Bucharest Early Intervention Project. Dev Psychol 52:1858-1866. CrossRef Medline

Amaral DG (2003) The amygdala, social behavior, and danger detection. Ann N Y Acad Sci 1000:337-347. CrossRef Medline

Anda RF, Felitti VJ, Bremner JD, Walker JD, Whitfield C, Perry BD, Dube SR, Giles WH (2006) The enduring effects of abuse and related adverse experiences in childhood: a convergence of evidence from neurobiology and epidemiology. Eur Arch Psychiatry Clin Neurosci 256:174-186. CrossRef Medline

Arp JM, Ter Horst JP, Loi M, den Blaauwen J, Bangert E, Fernandez G, Joëls M, Oitzl MS, Krugers HJ (2016) Blocking glucocorticoid receptors at adolescent age prevents enhanced freezing between repeated cue-exposures after conditioned fear in adult mice raised under chronic early life stress. Neurobiol Learn Mem 133:30-38. CrossRef Medline

Atwal JK, Pinkston-Gosse J, Syken J, Stawicki S, Wu Y, Shatz C, TessierLavigne M (2008) PirB is a functional receptor for myelin inhibitors of axonal regeneration. Science 322:967-970. CrossRef Medline

Bale TL (2011) Sex differences in prenatal epigenetic programming of stress pathways. Stress 14:348-356. CrossRef Medline

Bale TL, Epperson CN (2015) Sex differences and stress across the lifespan. Nat Neurosci 18:1413-1420. CrossRef Medline

Bansal Y, Kuhad A (2016) Mitochondrial dysfunction in depression. Curr Neuropharmacol 14:610-618. CrossRef Medline

Barkat TR, Polley DB, Hensch TK (2011) A critical period for auditory thalamocortical connectivity. Nat Neurosci 14:1189-1194. CrossRef Medline

Baron-Cohen S, Ring HA, Bullmore ET, Wheelwright S, Ashwin C, Williams SC (2000) The amygdala theory of autism. Neurosci Biobehav Rev 24: 355-364. CrossRef Medline

Bath KG, Schilit A, Lee FS (2013) Stress effects on BDNF expression: effects of age, sex, and form of stress. Neuroscience 239:149-156. CrossRef Medline

Bath KG, Manzano-Nieves G, Goodwill H (2016) Early life stress accelerates behavioral and neural maturation of the hippocampus in male mice. Horm Behav 82:64-71. CrossRef Medline

Bath KG, Nitenson AS, Lichtman E, Lopez C, Chen W, Gallo M, Goodwill H, Manzano-Nieves G (2017) Early life stress leads to developmental and sex selective effects on performance in a novel object placement task. Neurobiol Stress 7:57-67. CrossRef Medline

Bauman MD, Lavenex P, Mason WA, Capitanio JP, Amaral DG (2004) The development of social behavior following neonatal amygdala lesions in rhesus monkeys. J Cogn Neurosci 16:1388-1411. CrossRef Medline

Bick J, Zhu T, Stamoulis C, Fox NA, Zeanah C, Nelson CA (2015) Effect of early institutionalization and foster care on long-term white matter development: a randomized clinical trial. JAMA Pediatr 169:211-219. CrossRef Medline

Bochner DN, Sapp RW, Adelson JD, Zhang S, Lee H, Djurisic M, Syken J, Dan Y, Shatz CJ (2014) Blocking PirB up-regulates spines and functional synapses to unlock visual cortical plasticity and facilitate recovery from amblyopia. Sci Transl Med 6:258ra140. CrossRef Medline

Bock J, Gruss M, Becker S, Braun K (2005) Experience-induced changes of dendritic spine densities in the prefrontal and sensory cortex: correlation with developmental time windows. Cereb Cortex 15:802-808. CrossRef Medline

Bos K, Fox NA, Zeanah CH, Nelson CA (2009) Effects of early psychosocial deprivation on the development of memory and executive function. Front Behav Neurosci 3:16. CrossRef Medline

Brenhouse HC, Andersen SL (2011) Nonsteroidal anti-inflammatory treatment prevents delayed effects of early life stress in rats. Biol Psychiatry 70:434-440. CrossRef Medline

Bronson SL, Bale TL (2014) Prenatal stress-induced increases in placental inflammation and offspring hyperactivity are male-specific and ameliorated by maternal antiinflammatory treatment. Endocrinology 155:26352646. CrossRef Medline

Bronson SL, Chan JC, Bale TL (2017) Sex-specific neurodevelopmental programming by placental insulin receptors on stress reactivity and sensorimotor gating. Biol Psychiatry 82:127-138. CrossRef Medline

Buzsáki G, Kaila K, Raichle M (2007) Inhibition and brain work. Neuron 56:771-783. CrossRef Medline

Cabungcal JH, Steullet P, Morishita H, Kraftsik R, Cuenod M, Hensch TK, Do KQ (2013) Perineuronal nets protect fast-spiking interneurons against oxidative stress. Proc Natl Acad Sci U S A 110:9130-9135. CrossRef Medline

Callaghan BL, Richardson R (2011) Maternal separation results in early emergence of adult-like fear and extinction learning in infant rats. Behav Neurosci 125:20-28. CrossRef Medline

Chang CC, Jou SH, Lin TT, Lai TJ, Liu CS (2015) Mitochondria DNA change and oxidative damage in clinically stable patients with major depressive disorder. PLoS One 10:e0125855. CrossRef Medline

Condé F, Lund JS, Lewis DA (1996) The hierarchical development of monkey visual cortical regions as revealed by the maturation of parvalbuminimmunoreactive neurons. Dev Brain Res 96:261-276. CrossRef Medline

Coplan JD, Trost RC, Owens MJ, Cooper TB, Gorman JM, Nemeroff CB, Rosenblum LA (1998) Cerebrospinal fluid concentrations of somatostatin and biogenic amines in grown primates reared by mothers exposed to manipulated foraging conditions. Arch Gen Psychiatry 55: 473-477. CrossRef Medline

Coutellier L, Würbel H (2009) Early environmental cues affect object recognition memory in adult female but not male C57BL/6 mice. Behav Brain Res 203:312-315. CrossRef Medline

Cover KK, Maeng LY, Lebrón-Milad K, Milad MR (2014) Mechanisms of estradiol in fear circuitry: implications for sex differences in psychopathology. Transl Psychiatry 4:e422. CrossRef Medline

Danese A, McEwen BS (2012) Adverse childhood experiences, allostasis, allostatic load, and age-related disease. Physiol Behav 106:29-39. CrossRef Medline

de Azeredo LA, Wearick-Silva LE, Viola TW, Tractenberg SG, Centeno-Silva A, Orso R, Schröder N, Bredy TW, Grassi-Oliveira R (2017) Maternal separation induces hippocampal changes in cadherin-1 (CDH-1) mRNA and recognition memory impairment in adolescent mice. Neurobiol Learn Mem 141:157-167. CrossRef Medline

de Campo DM, Cameron JL, Miano JM, Lewis DA, Mirnics K, Fudge JL (2017) Maternal deprivation alters expression of neural maturation gene tbr1 in the amygdala paralaminar nucleus in infant female macaques. Dev Psychobiol 59:235-249. CrossRef Medline

del Río JA, de Lecea L, Ferrer I, Soriano E (1994) The development of parvalbumin-immunoreactivity in the neocortex of the mouse. Dev Brain Res 81:247-259. CrossRef Medline

Dickendesher TL, Baldwin KT, Mironova YA, Koriyama Y, Raiker SJ, Askew KL, Wood A, Geoffroy CG, Zheng B, Liepmann CD, Katagiri Y, Benowitz LI, Geller HM, Giger RJ (2012) NgR1 and NgR3 are receptors for chondroitin sulfate proteoglycans. Nat Neurosci 15:703-712. CrossRef Medline

Do KQ, Cuenod M, Hensch TK (2015) Targeting oxidative stress and aberrant clinical period plasticity in the developmental trajectory to schizophrenia. Schizophr Bull 41: 835-846. CrossRef Medline

Drevets WC, Bogers W, Raichle ME (2002) Functional anatomical correlates of antidepressant drug treatment assessed using PET measures of regional glucose metabolism. Eur Neuropsychopharmacol 12:527-544. CrossRef Medline

Eaton NR, Keyes SM, Krueger RF, Balsis S, Skodol AE, Markon KE, Grant BF, Hasin DS (2012) An invariant dimensional liability model of gender differences in mental disorder prevalence: evidence from a national sample. J Abnorm Psychol 12:282-288. CrossRef Medline

Eaves LJ, Silberg JL, Meyer JM, Maes HH, Simonoff E, Pickles A, Rutter M, Neale MC, Reynolds CA, Erikson MT, Heath AC, Loeber R, Truett KR, Hewitt JK (1997) Genetics and developmental psychopathology: 2. The main effects of genes and environment on behavioral problems in the Virginia twin study of adolescent behavioral development. J Child Psychol Psychiatry 38:965-980. CrossRef Medline

Edwards VJ, Holden GW, Felitti VJ, Anda RF (2003) Relationship between multiple forms of childhood maltreatment and adult mental health in community respondents: results from the adverse childhood experiences study. Am J Psychiatry 160:1453-1460. CrossRef Medline

Ellis BJ, Boyce WT (2011) Differential susceptibility to the environment: toward an understanding of sensitivity to developmental experiences and context. Dev Psychopathol 23:1-5. CrossRef Medline 
Elston GN, Oga T, Fujita I (2009) Spinogenesis and pruning scales across functional hierarchies. J Neurosci 29:3271-3275. CrossRef Medline

Emery NJ, Capitanio JP, Mason WA, Machado CJ, Mendoza SP, Amaral DG (2001) The effects of bilateral lesions of the amygdala on dyadic social interactions in rhesus monkeys (Macaca mulatta). Behav Neurosci 115: 515-544. CrossRef Medline

Etkin A, Klemenhagen KC, Dudman JT, Rogan MT, Hen R, Kandel ER, Hirsch J (2004) Individual differences in trait anxiety predict the response of the basolateral amygdala to unconsciously processed fearful faces. Neuron 44:1043-1055. CrossRef Medline

Felitti VJ, Anda RF, Nordenberg D, Williamson DF, Spitz AM, Edwards V, Koss MP, Marks JS (1998) Relationship of childhood abuse and household dysfunction to many of the leading causes of death in adults: the Adverse Childhood Experiences (ACE) Study. Am J Prev Med 14:245258. CrossRef Medline

Fuentes I, Eller O, Pierce A, Christianson J (2016) Sex differences in an early life stress mouse model of comorbid mood disorder and urogenital pain. J Pain 17:S69. CrossRef

Gaignard P, Savouroux S, Liere P, Pianos A, Thérond P, Schumacher M, Slama A, Guennoun R (2015) Effect of sex differences on brain mitochondrial function and its suppression by ovariectomy and in aged mice. Endocrinology 156:2893-2904. CrossRef Medline

Gilles EE, Schultz L, Baram TZ (1996) Abnormal corticosterone regulation in an immature rat model of continuous chronic stress. Pediatr Neurol 15:114-119. CrossRef Medline

Goel N, Bale TL (2009) Examining the intersection of sex and stress in modelling neuropsychiatric disorders. J Neuroendocrinol 21:415-420. CrossRef Medline

Gogolla N, Caroni P, Lüthi A, Herry C (2009) Perineuronal nets protect fear memories from erasure. Science 325:1258-1261. CrossRef Medline

Gogolla N, Takesian AE, Feng G, Fagiolini M, Hensch TK (2014) Sensory integration in mouse insular cortex reflects GABA circuit maturation. Neuron 83:894-905. CrossRef Medline

Grattagliano I, de Bari O, Bernardo TC, Oliveira PJ, Wang DQ, Portincasa P (2012) Role of mitochondria in nonalcoholic fatty liver disease: from origin to propagation. Clin Biochem 45:610-618. CrossRef Medline

Gross CM, Flubacher A, Tinnes S, Heyer A, Scheller M, Herpfer I, Berger M, Frotscher M, Lieb K, Haas CA (2012) Early life stress stimulates hippocampal reelin gene expression in a sex-specific manner: evidence for corticosterone-mediated action. Hippocampus 22:409-420. CrossRef Medline

Gunn BG, Cunningham L, Cooper MA, Corteen NL, Seifi M, Swinny JD, Lambert JJ, Belelli D (2013) Dysfunctional astrocytic and synaptic regulation of hypothalamic glutamatergic transmission in a mouse model of early-life adversity: relevance to neurosteroids and programming of the stress response. J Neurosci 33:19534-19554. CrossRef Medline

Gunnar MR, Frenn K, Wewerka SS, Van Ryzin MJ (2009) Moderate versus severe early life stress: associations with stress reactivity and regulation in 10-12-year-old children. Psychoneuroendocrinology 34:62-75. CrossRef Medline

Harlow HF, Suomi SJ (1974) Induced depression in monkeys. Behav Biol 12:273-296. CrossRef Medline

Harlow HF, Zimmermann RR (1959) Affectional responses in the infant monkey; orphaned baby monkeys develop a strong and persistent attachment to inanimate surrogate others. Science 130:421-432. CrossRef Medline

Hart H, Rubia K (2012) Neuroimaging of child abuse: a critical review. Front Human Neurosci 6:1-24. CrossRef Medline

Harte MK, Powell SB, Swerdlow NR, Geyer MA, Reynolds GP (2007) Deficits in parvalbumin and calbindin immunoreactive cells in the hippocampus of isolation reared rats. J Neural Transm 114:893-898. CrossRef Medline

Hensch TK (2004) Critical period regulation. Annu Rev Neurosci 27:549579. CrossRef Medline

Hensch TK (2005) Critical period plasticity in local cortical circuits. Nat Rev Neurosci 6:877-888. CrossRef Medline

Hensch TK, Fagiolini M, Mataga N, Stryker MP, Baekkeskov S, Kash SF (1998) Local GABA circuit control of experience-dependent plasticity in the developing visual cortex. Science 282:1504-1508. CrossRef Medline

Heun-Johnson H, Levitt P (2016) Early-life stress paradigm transiently alters maternal behavior, dam-pup interactions, and offspring vocalizations in mice. Front Behav Neurosci 10:1-18. CrossRef Medline

Hodge RD, Kahoud RJ, Hevner RF (2012) Transcriptional control of gluta- materic differentiation during adult neurogenesis. Cell Mol Life Sci 69: 2125-2134. CrossRef Medline

Holland FH, Ganguly P, Potter DN, Chartoff EH, Brenhouse HC (2014) Early life stress disrupts social behavior and prefrontal cortex parvalbumin interneurons at an earlier time-point in females than in males. Neurosci Lett 566:131-136. CrossRef Medline

Hong S, Stevens B (2016) Microglia: phagocytosing to clear, sculpt, and eliminate. Dev Cell 38:126-128. CrossRef Medline

Howerton CL, Bale TL (2014) Targeted placental deletion of OGT recapitulates the prenatal stress phenotype including hypothalamic mitochondrial dysfunction. Proc Natl Acad Sci U S A 111:9639-9644. CrossRef Medline

Huang ZJ, Kirkwood A, Pizzorusso T, Porciatti V, Morales B, Bear MF, Maffei L, Tonegawa S (1999) BDNF regulates the maturation of inhibition and the critical period of plasticity in mouse visual cortex. Cell 98:739-755. CrossRef Medline

Humphreys KL, Gleason MM, Drury SS, Miron D, Nelson CA 3rd, Fox NA, Zeanah CH (2015) Effects of early deprivation on psychopathology at age 12 years: follow-up of a randomized controlled trial. Lancet Psychiatry 2:625-634. CrossRef Medline

Irwin RW, Yao J, To J, Hamilton RT, Cadenas E, Brinton RD (2012) Selective oestrogen receptor modulators differentially potentiate brain mitochondrial function. J Neuroendocrinol 24:236-248. CrossRef Medline

Jenkins TA, Harte MK, Stenson G, Reynolds GP (2009) Neonatal lipopolysaccharide induces pathological changes in parvalbumin immunoreactivity in the hippocampus of the rat. Behav Brain Res 205:355-359. CrossRef Medline

Kawakami SE, Quadros IM, Takahashi S, Suchecki D (2007) Long maternal separation accelerates behavioural sensitization to ethanol in female, but not in male mice. Behav Brain Res 184:109-116. CrossRef Medline

Kawakami SE, Quadros IM, Machado RB, Suchecki D (2013) Sex-dependent effects of maternal separation on plasma corticosterone and brain monoamines in response to chronic ethanol administration. Neuroscience 253: 55-66. CrossRef Medline

Kessler RC, Sonnega A, Bromet E, Hughes M, Nelson CB (1995) Posttraumatic-stress-disorder in the National Comorbidity Survey. Arch Gen Psychiatry 52:1048-1060. CrossRef Medline

Keyes KM, Eaton NR, Krueger RF, McLaughlin KA, Wall MM, Grant BF, Hasin DS (2012) Childhood maltreatment and the structure of common psychiatric disorders. Br J Psychiatry 200:107-115. CrossRef Medline

Kikusui T, Mori Y (2009) Behavioural and neurochemical consequences of early weaning in rodents. J Neuroendocrinol 21:427-431. CrossRef Medline

Klinedinst NJ, Regenold WT (2015) A mitochondrial bioenergetic basis of depression. J Bioenerg Biomembr 47:155-171. CrossRef Medline

Knudsen EI, Heckman JJ, Cameron JL, Shonkoff JP (2006) Economic, neurobiological, and behavioral perspectives on building America's future workforce. Proc Natl Acad Sci U S A 103:10155-10162. CrossRef Medline

Kobayashi Y, Ye Z, Hensch TK (2015) Clock genes control cortical critical period timing. Neuron 86:264-275. CrossRef Medline

Kohl C, Wang XD, Grosse J, Fournier C, Harbich D, Westerholz S, Li JT, Bacq A, Sippel C, Hausch F, Sandi C, Schmidt MV (2015) Hippocampal neuroligin-2 links early-life stress with impaired social recognition and increased aggression in adult mice. Psychoneuroendocrinology 55:128 143. CrossRef Medline

Koliaki C, Roden M (2016) Alterations of mitochondrial function and insulin sensitivity in human obesity and diabetes mellitus. Annu Rev Nutr 36:337-367. CrossRef Medline

LeBlanc JJ, Fagiolini M (2011) Autism: a "critical period" disorder? Neural Plast 2011:2011:921680. CrossRef Medline

Leonardo ED, Hen R (2008) Anxiety as a developmental disorder. Neuropsychopharmacology 33:134-140. CrossRef Medline

Lerch S, Dormann C, Brandwein C, Gass P, Chourbaji S (2016) The scent of stress: environmental challenge in the peripartum environment of mice affects emotional behaviours of the adult offspring in a sex-specific manner. Lab Anim 50:167-178. CrossRef Medline

Lewis DA, Curley AA, Glausier JR, Volk DW (2012) Cortical parvalbumin interneurons and cognitive dysfunction in schizophrenia. Trends Neurosci 35:57-67. CrossRef Medline

Liao XM, Yang XD, Jia J, Li JT, Xie XM, Su YA, Schmidt MV, Si TM, Wang XD (2014) Blockade of corticotropin-releasing hormone receptor 1 attenuates early-life stress-induced synaptic abnormalities in the neonatal hippocampus. Hippocampus 24:528-540. CrossRef Medline 
Liu R, Yang XD, Liao XM, Xie XM, Su YA, Li JT, Wang XD, Si TM (2016) Early postnatal stress suppresses the developmental trajectory of hippocampal pyramidal neurons: the role of CRHR1. Brain Struct Funct 221:4525-4536. CrossRef Medline

Lorberbaum JP, Kose S, Johnson MR, Arana GW, Sullivan LK, Hamner MB, Ballenger JC, Lydiard RB, Brodrick PS, Bohning DE, George MS (2004) Neural correlates of speech anticipatory anxiety in generalized social phobia. Neuroreport 15:2701-2705. Medline

Malter Cohen M, Jing D, Yang RR, Tottenham N, Lee FS, Casey BJ (2013) Early-life stress has persistent effects on amygdala function and development in mice and humans. Proc Natl Acad Sci U S A 110:18274-18278. CrossRef Medline

Mandal S, Stanco A, Buys ES, Enikolopov G, Rubenstein JL (2013) Soluble guanylate cyclase generation of cGMP regulates migration of MGE neurons. J Neurosci 33:16897-16914. CrossRef Medline

Marco EM, Velarde E, Llorente R, Laviola G (2016) Disrupted circadian rhythm as a common player in developmental models of neuropsychiatric disorders. Curr Top Behav Neurosci 29:155-181. CrossRef Medline

Marín O (2012) Interneuron dysfunction in psychiatric disorders. Nat Rev Neurosci 13:107-120. CrossRef Medline

Marín O (2016) Developmental timing and critical windows for the treatment of psychiatric disorders. Nat Med 22:1229-1238. CrossRef Medline

Marshall PJ, Fox NA (2004) A comparison of the electroencephalogram between institutionalized and community children in Romania. J Cogn Neurosci 168:1327-1338. Medline

Mataga N, Mizuguchi Y, Hensch TK (2004) Experience-dependent pruning of dendritic spines in visual cortex by tissue plasminogen activator. Neuron 44:1031-1041. CrossRef Medline

McEwen BS, Bowles NP, Gray JD, Hill MN, Hunter RG, Karatsoreos IN, Nasca C (2015) Mechanisms of stress in the brain. Nat Neurosci 18: 1353-1363. CrossRef Medline

McEwen CA, McEwen BS (2017) Social structure, adversity, toxic stress, and intergenerational poverty: an early childhood model. Annu Rev Sociol 43:29.21-29.28.

McGoron L, Gleason MM, Smyke AT, Drury SS, Nelson CA, Gregas MC, Fox NA, Zeanah CH (2012) Recovering from early deprivation: attachment mediates effects of caregiving on psychopathology. J Am Acad Child Adol Psychiatry 51:683-693. CrossRef Medline

McIlwrick S, Rechenberg A, Matthes M, Burgstaller J, Schwarzbauer T, Chen A, Touma C (2016) Genetic predisposition for high stress reactivity amplifies effects of early-life adversity. Psychoneuroendocrinology 70:85-97. CrossRef Medline

McIlwrick S, Pohl T, Chen A, Touma C (2017) Late-onset cognitive impairments after early-life stress are shaped by inherited differences in stress reactivity. Front Cell Neurosci 11:9. CrossRef Medline

McLaughlin KA, Zeanah CH, Fox NA, Nelson CA (2012) Attachment security as a mechanism linking foster care placement to improved mental health outcomes in previously institutionalized children. J Child Psychol Psychiatry 53:46-55. CrossRef Medline

McLaughlin KA, Sheridan MA, Tibu F, Fox NA, Zeanah CH, Nelson CA (2015) Causal effects of the early caregiving environment on development of stress response systems in children. Proc Natl Acad Sci U S A 112:298-313. CrossRef Medline

Mehta M, Schmauss C (2011) Strain-specific cognitive deficits in adult mice exposed to early life stress. Behav Neurosci 125:29-36. CrossRef Medline

Meyer U, Nyffeler M, Yee BK, Knuesel I, Feldon J (2008) Adult brain and behavioral pathological markers of prenatal immune challenge during early/middle and late fetal development in mice. Brain Behav Immun 22:469-486. CrossRef Medline

Millstein RA, Holmes A (2007) Effects of repeated maternal separation on anxiety- and depression-related phenotypes in different mouse strains. Neurosci Biobehav Rev 31:3-17. CrossRef Medline

Moore CL, Morelli GA (1979) Mother rats interact differently with male and female offspring. J Comp Physiol Psychol 93:677-684. CrossRef Medline

Morishita H, Cabungcal JH, Chen Y, Do KQ, Hensch TK (2015) Prolonged period of cortical plasticity upon redox dysregulation in fast-spiking interneurons. Biol Psychiatry 78:396-402. CrossRef Medline

Mueller BR, Bale TL (2007) Early prenatal stress impact on coping strategies and learning performance is sex dependent. Physiol Behav 91:55-65. CrossRef Medline

Mueller BR, Bale TL (2008) Sex-specific programming of offspring emotionality after stress early in pregnancy. J Neurosci 28:9055-9065. CrossRef Medline

Naninck EF, Hoeijmakers L, Kakava-Georgiadou N, Meesters A, Lazic SE, Lucassen PJ, Korosi A (2015) Chronic early life stress alters developmental and adult neurogenesis and impairs cognitive function in mice. Hippocampus 25:309-328. CrossRef Medline

Nelson CA, Bloom FE, Cameron JL, Amaral D, Dahl RE, Pine D (2002) An integrative, multidisciplinary approach to the study of brain-behavior relations in the context of typical and atypical development. Dev Psychopathol 14:499-520. Medline

Nelson CA 3rd, Zeanah CH, Fox NA, Marshall PJ, Smyke AT, Guthrie D (2007) Cognitive recovery in socially deprived young children: the Bucharest Early Intervention Project. Science 318:1937-1940. CrossRef Medline

Nelson CA, Fox NA, Zeanah CH (2014) Romania's abandoned children: deprivation, brain development and the struggle for recovery. Cambridge, MA: Harvard UP.

Nelson CA, Fox NA, Zeanah CH (2016) The effects of early psychosocial deprivation on brain and behavioral development: findings from the $\mathrm{Bu}-$ charest Early Intervention Project. In: Developmental psychopathology, Ed 4 (Cicchetti D, ed), pp 1-37. New York: Wiley.

O'Connor TG, Cameron JL (2006) Translating research findings on early experience to prevention: animal and human evidence on early attachment relationships. Am J Prev Med 31:S175-S181. CrossRef Medline

Pechtel P, Pizzagalli DA (2011) Effects of early life stress on cognitive and affective function: an integrated review of human literature. Psychopharmacology 214:55-70. CrossRef Medline

Pena CJ, Kronman HG, Walker DM, Cates HM, Bagot RC, Purushothaman I, Issler O, Loh YE, Leong T, Kiraly DD, Goodman E, Neve RL, Shen L, Nestler EJ (2017) Early life stress confers lifelong stress susceptibility in mice via ventral tegmental area OTX2. Science 356:1185-1188. CrossRef Medline

Peng Y, Lu Z, Li G, Piechowicz M, Anderson M, Uddin Y, Wu J, Qiu S (2016) The autism-associated MET receptor tyrosine kinase engages early neuronal growth mechanism and controls glutamatergic circuits development in the forebrain. Mol Psychiatry 21:925-935. CrossRef Medline

Pessayre D (2007) Role of mitochondria in non-alcoholic fatty liver disease. J Gastroenterol Hepatol 22 [Suppl 1]:S20-S27.

Picard M, McEwen BS (2014) Mitochondria impact brain function and cognition. Proc Natl Acad Sci U S A 111:7-8. CrossRef Medline

Picard M, Juster RP, McEwen BS (2014) Mitochondrial allostatic load puts the 'gluc' back in glucocorticoids. Nat Rev Endocrinol 10:303-310. CrossRef Medline

Picard M, McManus MJ, Gray JD, Nasca C, Moffat C, Kopinski PK, Seifert EL, McEwen BS, Wallace DC (2015) Mitochondrial functions modulate neuroendocrine, metabolic, inflammatory, and transcriptional responses to acute psychological stress. Proc Natl Acad Sci U S A 112:E6614-E6623. CrossRef Medline

Picard M, Juster RP, Sloan RP, McEwen BS (2017) Mitochondrial nexus to allostatic load biomarkers. Psychosom Med 79:114-117. CrossRef Medline

Qiu S, Lu Z, Levitt P (2014) MET receptor tyrosine kinase controls dendritic complexity, spine morphogenesis, and glutamatergic synapse maturation in the hippocampus. J Neurosci 34:16166-16179. CrossRef Medline

Rettberg JR, Yao J, Brinton RD (2014) Estrogen: a master regulator of bioenergetic systems in the brain and body. Front Neuroendocrinol 35:8-30. CrossRef Medline

Rice CJ, Sandman CA, Lenjavi MR, Baram TZ (2008) A novel mouse model for acute and long-lasting consequences of early life stress. Endocrinology 149:4892-4900. CrossRef Medline

Sabatini MJ, Ebert P, Lewis DA, Levitt P, Cameron JL, Mirnics K (2007) Amygdala gene expression correlates of social behavior in monkeys experiencing maternal separation. J Neurosci 27:3295-3304. CrossRef Medline

Sánchez MM, Ladd CO, Plotsky PM (2001) Early adverse experience as a developmental risk factor for later psychopathology: evidence from rodent and primate models. Dev Psychopathol 13:419-449. CrossRef Medline

Savignac HM, Dinan TG, Cryan JF (2011) Resistance to early life stress in mice: effects of genetic background and stress duration. Front Behav Neurosci 5:13. CrossRef Medline

Schiavone S, Sorce S, Dubois-Dauphin M, Jaquet V, Colaianna M, Zotti M, Cuomo V, Trabace L, Krause KH (2009) Involvement of NOX2 in the 
development of behavioral and pathologic alterations in isolated rats. Biol Psychiatry 66:384-392. CrossRef Medline

Serviddio G, Sastre J, Bellanti F, Viña J, Vendemiale G, Altomare E (2008) Mitochondrial involvement in non-alcoholic steatohepatitis. Mol Aspects Med 29:22-35. CrossRef Medline

Sheridan MA, McLaughlin KA (2014) Dimensions of early experience and neural development: deprivation and threat. Trends Cogn Sci 18:580585. CrossRef Medline

Sheridan MA, Fox NA, Zeanah CH, McLaughlin KA, Nelson CA 3rd (2012) Variation in neural development as a result of exposure to institutionalization early in childhood. Proc Natl Acad Sci U S A 109:12927-12932. CrossRef Medline

Simonoff E, Pickles A, Meyer JM, Silberg JL, Maes HH, Loeber R, Rutter M, Hewitt JK, Eaves LJ (1997) The Virginia Twin Study of Adolescent Behavioral Development: influences of age, sex, and impairment on rates of disorder. Arch Gen Psychiatry 54:801-808. CrossRef Medline

Smyke AT, Koga SF, Johnson DE, Fox NA, Marshall PJ, Nelson CA, Zeanah $\mathrm{CH}$ (2007) The caregiving context in institution-reared and familyreared infants and toddlers in Romania. J Child Psychol Psychiatry 4:210218. CrossRef Medline

Smyke AT, Zeanah CH, Fox NA, Nelson CA (2009) A new model of foster care for young children: the Bucharest Early Intervention Project. Child Adolesc Psychiatr Clin North Am 18:721-734. CrossRef Medline

Smyke AT, Zeanah CH, Fox NA, Nelson CA, Guthrie D (2010) Placement in foster care enhances quality of attachment among young institutionalized children. Child Dev 81:212-223. CrossRef Medline

Somers JM, Goldner EM, Waraich P, Hsu L (2006) Prevalence and incidence studies of anxiety disorders: a systematic review of the literature. Can J Psychiatry 51:100-113. CrossRef Medline

Spinelli S, Chefer S, Suomi SJ, Higley JD, Barr CS, Stein E (2009) Early-life stress induces long-term morphologic changes in primate brain. Arch Gen Psychiatry 66:658-665. CrossRef Medline

Spinelli S, Chefer S, Carson RE, Jagoda E, Lang L, Heilig M, Barr CS, Suomi SJ, Higley JD, Stein EA (2010) Effects of early-life stress on serotonin(1A) receptors in juvenile Rhesus monkeys measured by positron emission tomography. Biol Psychiatry 67:1146-1153. CrossRef Medline

Sugiyama S, Di Nardo AA, Aizawa S, Matsuo I, Volovitch M, Prochiantz A, Hensch TK (2008) Experience-dependent transfer of Otx2 homeoprotein into the visual cortex activates postnatal plasticity. Cell 134:508-520. CrossRef Medline

Suomi SJ, Eisele CD, Grady SA, Harlow HF (1975) Depressive behavior in adult monkeys following separation from family environment. J Abnorm Psychol 84:576-578. CrossRef Medline

Takatsuru Y, Yoshitomo M, Nemoto T, Eto K, Nabekura J (2009) Maternal separation decreases the stability of mushroom spines in adult mice somatosensory cortex. Brain Res 1294:45-51. CrossRef Medline

Takatsuru Y, Nabekura J, Ishikawa T, Kohsaka S, Koibuchi N (2015) Earlylife stress increases the motility of microglia in adulthood. J Physiol Sci 65:187-194. CrossRef Medline

Takesian AE, Hensch TK (2013) Balancing plasticity/stability across brain development. Prog Brain Res 207:3-34. CrossRef Medline

Vanderwert RE, Marshall PJ, Nelson CA 3rd, Zeanah CH, Fox NA (2010) Timing of intervention affects brain electrical activity in children exposed to severe psychosocial neglect. PLoS One 5:e11415. CrossRef Medline

Vanderwert RE, Zeanah CH, Fox NA, Nelson CA 3rd (2016) Normalization of EEG activity among previously institutionalized children placed into foster care: a 12 year follow-up of the Bucharest Early Intervention Project. Dev Cogn Neurosci 17:68-75. CrossRef Medline
Walker CD, Bath KG, Marian J, Aniko K, Muriel L, Lucassen PJ, Morris M, Charlis R, Roth TL, Sullivan RM, Yvette T, Baram TZ (2017) Chronic early life stress induced by limited bedding and nesting (LBN) material in rodents: critical considerations of methodology, outcomes and translational potential. Stress. Advance online publication. Retrieved Jul. 12, 2017. doi: 10.1080/10253890.2017.1343296. CrossRef Medline

Wallace DC (1999) Mitochondrial diseases in man and mouse. Science 283: 1482-1488. CrossRef Medline

Wanagat J, Hevener AL (2016) Mitochondrial quality control in insulin resistance and diabetes. Curr Opin Genet Dev 38:118-126. CrossRef Medline

Wang XD, Rammes G, Kraev I, Wolf M, Liebl C, Scharf SH, Rice CJ, Wurst W, Holsboer F, Deussing JM, Baram TZ, Stewart MG, Müller MB, Schmidt MV (2011) Forebrain CRF(1) modulates early-life stress-programmed cognitive deficits. J Neurosci 31:13625-13634. CrossRef Medline

Wang XD, Labermaier C, Holsboer F, Wurst W, Deussing JM, Müller MB, Schmidt MV (2012) Early-life stress-induced anxiety-related behavior in adult mice partially requires forebrain corticotropin-releasing hormone receptor 1. Eur J Neurosci 36:2360-2367. CrossRef Medline

Wang XD, Su YA, Wagner KV, Avrabos C, Scharf SH, Hartmann J, Wolf M, Liebl C, Kühne C, Wurst W, Holsboer F, Eder M, Deussing JM, Müller MB, Schmidt MV (2013) Nectin-3 links CRHR1 signaling to stressinduced memory deficits and spine loss. Nat Neurosci 16:706-713. CrossRef Medline

Werner C, Raivich G, Cowen M, Strekalova T, Sillaber I, Buters JT, Spanagel R, Hofmann F (2004) Importance of NO/cGMP signalling via cGMPdependent protein kinase II for controlling emotionality and neurobehavioral effects of alcohol. Eur J Neurosci 20:3498-3506. CrossRef Medline

Winslow JT (2005) Neuropeptides and nonhuman primate social deficits associated with pathogenic rearing experience. In J Dev Neurosci 23:245251. CrossRef

Xie L, Korkmaz KS, Braun K, Bock J (2013) Early life stress-induced histone acetylations correlate with activation of the synaptic plasticity genes Arc and Egrl in the mouse hippocampus. J Neurochem 125:457-464. CrossRef Medline

Yam KY, Naninck EF, Abbink MR, la Fleur SE, Schipper L, van den Beukel JC, Grefhorst A, Oosting A, van der Beek EM, Lucassen PJ, Korosi A (2017) Exposure to chronic early-life stress lastingly alters the adipose tissue, the leptin system and changes the vulnerability to Western-style diet later in life in mice. Psychoneuroendocrinology 77:186-195. CrossRef Medline

Yang XD, Liao XM, Uribe-Mariño A, Liu R, Xie XM, Jia J, Su YA, Li JT, Schmidt MV, Wang XD, Si TM (2015) Stress during a critical postnatal period induces region-specific structural abnormalities and dysfunction of the prefrontal cortex via CRF1. Neuropsychopharmacology 40:12031215. CrossRef Medline

Yin F, Yao J, Sancheti H, Feng T, Melcangi RC, Morgan TE, Finch CE, Pike CJ, Mack WJ, Cadenas E, Brinton RD (2015) The perimenopausal aging transition in the female rat brain: decline in bioenergetic systems and synaptic plasticity. Neurobiol Aging 36:2282-2295. CrossRef Medline

Zeanah CH, Nelson CA, Fox NA, Smyke AT, Marshall P, Parker SW, Koga S (2003) Designing research to study the effects of institutionalization on brain and behavioral development: the Bucharest Early Intervention Project. Dev Psychopathol 15:885-907. Medline

Zeanah CH, Smyke AT, Koga SF, Carlson E (2005) Attachment in institutionalized and community children in Romania. Child Dev 76:10151028. CrossRef Medline

Zeanah CH, Egger HL, Smyke AT, Nelson CA, Fox NA, Marshall PJ, Guthrie D (2009) Institutional rearing and psychiatric disorders in Romanian preschool children. Am J Psychiatry 166:777-785. CrossRef Medline 